\title{
Consumer debt delinquency by family lifecycle categories
}

\section{Postprint.}

For published article see:

Xiao, J. J., Yao, R., \& Liao, L. (2014). Consumer debt delinquency by family lifecycle categories. International Journal of Bank Marketing, 32(1), 43-59.

\begin{abstract}
Purpose - The purpose of this paper is to document debt delinquency patterns by family lifecycle categories using multiple data sets that are nationally representative of American families.

Design/methodology/approach - Based on previous research, 15 lifecycle categories appropriate for American families are defined by household head's age, marital status, presence of children, and age of children. Data used are from Surveys of Consumer Finances (SCF) in the USA in 1992-2010. Multiple logistic regressions are conducted to identify probabilities of debt delinquencies of families in various lifecycle categories by controlling for income, financial assets, holdings of several types of debt, and several other demographic and socioeconomic variables.

Findings - The results show that among the 15 household lifecycle categories, the top three most likely to be delinquent are young couples with children aged seven or older, middle-aged singles with children aged 15 or older, and middle-aged singles with children under 15 . Younger households are more financially distressed than their older counterparts. Presence of children increases the probability of debt delinquency.

Research limitations/implications - In this study, multiple national data sets representing American families are used to document debt delinquency patterns by family lifecycle
\end{abstract}


categories. Results shed light on this important topic and offer helpful information for both banking industry practitioners and consumer financial educators.

Practical implications - The information produced by this study can help bank managers better identify their potential clients and understand their current customers. Different marketing strategies based on the research findings can be developed to attract and retain customers with different delinquency risks.

Originality/value - This is the first study to examine debt delinquencies by family lifecycle categories with multiple SCF data sets in the USA. The 15 family lifecycle categories used are based on recent research that is specially designed for American families. The research findings provide straightforward implications for both bank managers and consumer educators.

Keywords Consumer behavior, Borrowing, Debt delinquency, Family lifecycle, Consumer credit, Survey of consumer finances 


\section{Introduction}

Non-performing loans have had a negative effect on banks' profitability and success. It is in the banks' vested interest to efficiently find, attract, and manage their customers, including identifying risks of different customer groups and developing strategies for these groups. The bank marketing literature has examined consumer credit issues in several aspects, such as card centric distribution of financial services (Worthington, 1998), affinity credit card market (Worthington and Horne, 1998), main and subsidiary credit card holding and spending (Devlin et al., 2007), debit and credit card usage and satisfaction (Foscht et al., 2010), and college students' consumption of credit cards (Blankson et al., 2012).

Unlike the aforementioned previous research on bank marketing, this study focusses on a different aspect of consumer credit: consumer debt delinquency behavior by family lifecycle stage categories. The findings of this study should help bank marketers identify borrowers' risks of being late on loans by various lifecycle categories given socioeconomic and demographic conditions, which should assist banks in maximizing their efficiency and profitability.

Consumer debt delinquency refers to late debt payment behavior, which would immediately result in lower credit scores, jeopardize consumers' opportunities to receive future consumer credit, and adversely affect consumer financial well-being (Getter, 2006; Lyons, 2003). More importantly, mass debt delinquency can affect the economy at the macro level. Excessive consumer debt might be one major reason for the recent recession in the USA (Lander, 2008). Beginning in the early 1980s, financial deregulations resulted in many financial innovations that provided more credit alternatives for consumers, but at the same time, also demanded a higher 
level of knowledge and skills for consumers to manage debts (Ryan et al., 2010). Because of financial deregulations and innovations in the last three decades, consumers have had broader access to credit. Despite the advantages of consumer credit, the broader access mostly decreased consumer financial well-being (Dynan, 2009).

To keep a balance between providing adequate credit for consumers and ensuring consumers can control their debts, there is increased demand for research on consumer debt delinquency. Previous research on debt delinquency focusses on influences of financial resources (Getter, 2003), marital status (Lyons and Fisher, 2006), family types (Sun and Xiao, 2007), and family hardships (McCloud and Dwyer, 2011).

This study focusses on the potential influence of family lifecycle categories and empirically estimates probabilities of debt delinquency by various lifecycle categories. Using family lifecycle categories to examine debt delinquency risks can provide a comprehensive picture on this topic and make unique contributions to the literature of consumer debt delinquency. This approach can help bank professionals pay attention to diverse needs of families in various lifecycle categories and provide differential strategies to serve their special needs.

Consumer borrowing behavior over the lifespan is of interest to bank professionals and consumer educators. The research question can be tackled with economic models under the utility framework, but evidence from behavioral economics shows that actual consumer behaviors violate many assumptions under the utility function (Thaler, 2000). In addition, because of the cognitive limitations of consumers and uncertainty of economic environments, it is difficult to 
plan and predict borrowing behavior over the lifespan. To overcome these difficulties, an alternative research approach is to empirically investigate how consumers act over various lifecycle stages. Since longitudinal data with debt delinquency and other related information are limited, this study uses multiple cross-sectional data to depict an overall picture of debt delinquency by lifecycle categories, which are nationally representative data from the 1992-2010 Surveys of Consumer Finances (SCF) in the USA.

Cross-sectional data are imperfect in terms of observing household level changes of debt delinquency over time, but findings from analyzing this type of data can shed light on the national average consumer behavior over the lifespan when relevant longitudinal data are unavailable. Compared to previous research on debt delinquent behavior, this approach is more comprehensive and innovative. In addition, this study used a unique categorization of lifecycle stages that is specifically appropriate for American families based on the work of Du and Kamakura (2006). Results of this study will increase understanding of consumer borrowing and repaying behavior and provide helpful information for bank professionals and consumer educators to better identify their potential clients and better serve their existing clients.

\section{Literature review on consumer debt delinquency}

Recent descriptive statistics of consumer debt delinquent behavior measured by the share of households of a given type, with missing debt payments for 60 or more days, can be found in Federal Reserve Board staff papers using data from various SCF (Aizcorbe et al., 2003; Bucks et al., 2006, 2009; Bricker et al., 2012). The trend of this measure among debtor households has increased with fluctuations since early 1990s, from 6 percent in 1992 to 10.8 percent in 2010. 
Using data from 1989-2007 SCF, Xiao and Yao (2011) found that the trend of the consumer debt delinquency rate has been stable at around 7.4 percent among debtor households. However, several family types, such as cohabiting with children and single-mother families, have about twice the average delinquency rate, 16.9 and 14.7 percent, respectively.

Previous research demonstrates that debt delinquency is associated with factors related to lifecycle categories. Using data from the $1983 \mathrm{SCF}$ to examine factors affecting late payment behavior, Canner and Luckett (1990) found that missing a debtpayment is associated with several variables related to lifecycle stages, such as marital status, age, or number of children. Lyons and Fisher (2006) examined debt repayment behavior using data from the 1991-1995 Panel Study of Income Dynamics (PSID) and found that divorced men and women are more likely than married individuals to default on debt payments. Using the 2004 SCF, Sun and Xiao (2007) concluded that variables related to lifecycle categories affect debt delinquency behavior. With the same data set, McCloud and Dwyer (2011) found that married couples with children and single females with children are more likely to be late in debt payments. The household head's age shows an inverse U-shape on the risk of debt default.

Two studies examined consumer debt holding by lifecycle categories. Baek and Hong (2004) used data from the 1998 SCF to examine factors related to two types of consumer debts: installment debt and credit card debt. Results of the double-hurdle model show that lifecycle categories significantly affect installment debt and credit card debt holdings and amounts. Yilmazer and DeVaney (2005) used data from the 2001 SCF to examine how types and amounts of household debt change over the lifecycle. In this study, age was used to measure the lifecycle 
categories. Results show that the likelihood of holding each type of debt and the amount of each type of debt as a percentage to total assets decreased with age. Probit results show that several factors related to lifecycle categories, such as age, marital status, and retirement status, affect debt ownership. To our knowledge, no previous research has examined the potential effect of lifecycle categories on debt delinquency behavior.

Economic factors contribute to the likelihood of being delinquent on debt. Getter (2003) used the 1998 SCF to study factors associated with debt delinquency behavior. In his study, delinquency is defined as having missed a debt payment. Logistic results show that the most important predictor of delinquency behavior is income shock (income unusually low compared to what you would expect in a normal year). In another study, per capita income reduces delinquency risk, number of children increases the risk, and welfare income decreases delinquency risk for divorced women but not for divorced men (Lyons and Fisher, 2006). McCloud and Dwyer (2011) examined the relationship between family hardships and financial troubles, including bankruptcy, default, and credit access. Their results show that family hardships including poor health, divorce, unemployment, and income disruption increase a household's likelihood to default in debt.

Debt default is not only an indicator of financial ill-being itself but also results in undesirable financial consequences, such as having a bad credit score, paying high interest rates, losing access to credit, filing bankruptcy, and other indicators of financial ill-health. Debt delinquent behavior is associated with having to pay high interest rates. For example, 23.14 percent of debtors who are late in payments for two months or longer have paid a high (20 percent or 
higher) interest rate compared to 7.69 percent of debtor households who make payments on time paying the same rate (Sun and Xiao, 2007). Moorman and Garasky (2008) used data from 19911996 PSID to examine factors associated with the risk of filing bankruptcy and concluded that having financial problems is positively associated with filing bankruptcy. Among financial problems reported by the respondents, the most common one is missed debt payments. Using SCF data, Johnson (2005) treated late payment behavior as an independent variable to predict the credit card holding status and found that late payment behavior is a significant predictor of not holding a credit card. Also, late payment behavior is more likely to be practiced by new credit card holders who are younger, unmarried, and have a low income, low wealth, and more children.

Another study (Demos and Center for Responsible Lending, 2005) that surveyed credit card use among low- and middle-income consumers nationwide found that seven out of ten households report using their credit cards as a safety net, paying for such things as car repairs, basic living expenses, medical expenses, and house repairs. About half of the households have missed a payment or were late in the last year, and nearly a quarter of households report paying a late fee at least once or twice in the past year.

Based on previous research, this study advances knowledge of debt delinquency behavior in several ways. First, this study focusses on debt delinquency behavior by lifecycle categories. This study uses a definition of lifecycle stages appropriate for American families based on a study that has empirically examined appropriate categorization of American family lifecycles (Du and Kamakura, 2006). Moreover, this study uses seven data sets of the US SCF from 1992 
to 2010 to study consumer financial delinquency and, therefore, is more comprehensive in data and time scopes than prior research on consumer debt delinquency.

\section{Conceptual framework and hypotheses}

Consumer debt delinquency is considered an indicator of financial ill-being. To help consumers enhance their financial well-being, key factors associated with debt delinquency need to be identified from a lifecycle perspective. When this happens, the knowledge can be used by bank professionals to design effective marketing strategies to better serve consumers' diverse needs of consumers in various lifecycle categories. Although the traditional lifecycle hypothesis (Modigliani and Brumberg, 1954; Modigliani, 1986) has been criticized for its unrealistic assumption that consumers are able to maximize their utilities and smooth their lifecycle consumption, it is still widely used as a general framework by researchers. Based on this framework, consumers strive to maximize their lifecycle utility by making intertemporal consumption choices. In doing so, they need to overcome their credit constraints, especially when they are young (Attanasio and Weber, 2010).

From an economic perspective, consumers assume a desirable consumption level. At some lifecycle stages, consumers might borrow to meet their level of desired consumption. Family compositions (marital status and presence of children) may affect consumption and borrowing behaviors (Browning and Crossley, 2001). Controlling for resources, younger households should be more likely to be credit constrained than their middle-aged and older counterparts. As such, younger households might be more likely to experience financial difficulties that increase their probability of debt delinquency. Research shows that the likelihood 
of holding each type of debt and the amount of each type of debt as a percentage to total assets decrease with age (Yilmazer and DeVaney, 2005).

Similarly, at a certain resource level, a household with children will have higher consumption needs that can result in a greater likelihood to engage in debt delinquency behavior than a childless household, which is supported by the research finding that married couples with children and single females with children are more likely to be late in debt payments (McCloud and Dwyer, 2011).

Finally, married households might be less likely to have debt delinquency issues since they often have income diversification (one more source of income than unmarried households). Research indicates that divorced men and women are more likely than married individuals to default on debt payments (Lyons and Fisher, 2006).

Based on the above discussion, we propose the following hypotheses:

H1. Compared to other age groups and controlling for other socioeconomic and demographic factors, young households are most likely to be debt delinquent.

H2. Single-headed households are more likely than their married counterparts to be debt delinquent, controlling for other socioeconomic and demographic factors.

H3. Households with children are more likely than their childless counterparts to be debt delinquent, controlling for other socioeconomic and demographic factors. 
H4. Young, single households with children have the highest probability to engage in debt delinquency, controlling for other socioeconomic and demographic factors.

H5. Old, married households without children have the lowest probability for debt delinquency, controlling for other socioeconomic and demographic factors.

In the literature of consumer lifecycle behavior, both prescriptive and descriptive approaches have been used. The prescriptive approach uses the framework of a utility function under various assumptions, especially those about constraints, to evaluate consumer behaviors and their deviation from what a well informed, rational consumer would do. The descriptive approach empirically examines and attempts to explain actual consumer behaviors. Among descriptive approaches, two lines of research exist, one using age as the focal independent variable and the other using lifecycle categories as the focal independent variable (Xiao et al., 2011). This study uses a descriptive approach with lifecycle categories as the focal independent variable.

The lifecycle category approach has been used for studying consumer behavior since the 1950s (Lansing and Morgan, 1955). Using the concept of family lifecycle, previous studies have examined various types of consumer behaviors, such as financial behaviors (Lansing and Kish, 1957), engagement in entertainment (Hisrich and Peters, 1974), energy consumption (Fritzche, 1981), and expenditures (Wagner and Hanna, 1983; Wilkes, 1995), to name a few. These studies use different demographic variables such as gender, age, marital status, presence and age of children, and retirement status to construct family lifecycle stages in various ways. 
Unlike previous research using lifecycle stage category as a focal variable, Du and Kamakura (2006) apply the first-order Markov process to data from the Panel Study on Income Dynamics (PSID) across 34 years and empirically estimate lifecycle stages in the USA. This results in lifecycle categories appropriate for American families. Since SCF data are collected from American families and used in this study, we construct lifecycle categories in the spirit of the work by Du and Kamakura (2006).

\section{Method}

Data

Data used in this study are from seven data sets - 1992, 1995, 1998, 2001, 2004, 2007, and 2010 SCF - with a combined sample size of 32,370 . The earlier SCF data sets are excluded from this study because 1992 was the first year that the SCF collected information on income shock (Getter, 2003), an important control variable needed for this study. The triennial survey is sponsored by the Federal Reserve Board and has comprehensive information about family finances. The survey provides information on family financial situations such as income, pension, assets, and debts. This survey also includes information about family demographic characteristics and their perceptions (Bucks et al., 2009).

The dependent variable

The dependent variable is debt delinquency, which is measured by being 60 or more days late in debt payment. This measure was used to measure debt burdens in previous research (e.g. Bucks et al., 2009).

Lifecycle category variable 
The focal independent variable, lifecycle stage category, is developed based on the work by $\mathrm{Du}$ and Kamakura (2006) with adjustments. Unlike previous studies on lifecycle stages that first conceptually categorize lifecycle stages and then use data to fit these categories, Du and Kamakura directly estimated lifecycle stages among American families using a longitudinal data set, the 1968-2001 PSID. Their initial results included 13-15 lifecycle stages. On the basis of the Bayesian information criterion, they chose 13 stages as their final result:

(1) $\mathrm{Co} / \mathrm{So}=$ single or young couple with no children;

(2) $\mathrm{C} 1=$ small household (couple) with children $<7$ years of age;

(3) $\mathrm{C} 2=$ large household (couple) with children $<15$ years of age;

(4) C3=large household (couple) with older children;

(5) C4=small household (couple) with children $<15$ years of age;

(6) $\mathrm{S} 1=$ single/divorced with no children;

(7) C5=small household with older children;

(8) C6=empty-nest couple;

(9) $\mathrm{S} 2=$ single/divorced with children $<15$ years of age;

(10) $\mathrm{S} 3=$ divorced/widow with older children;

(11) S5=widowed empty nest;

(12) S4=divorced/single empty nest; and

(13) $\mathrm{C} 7=$ retired/older couple with adult dependents.

Factors involved in these stages include marital status, presence of children, age of children, family size, and adult dependent status. In addition, age of the respondents is an implicit factor in these categories. For example, stage 11 implies old age (65 years and older). The 13 lifecycle 
stages proposed by Du and Kamakura (2006) are specific to the data they use. Some of the criteria are not definitive (e.g. young couple, small household), and the criteria used to define the stages are not consistent. Inspired by the work of Du and Kamakura (2006) and previous research on consumer lifecycle behavior (Lansing and Kish, 1957; Hisrich and Peters, 1974; Fritzche, 1981; Wagner and Hanna, 1983; Wilkes, 1995), we have considered the following factors in our study: age, marital status, presence of children, age of children, and presence of financial dependents.

After several trials with different combinations of various lifecycle-related variables to achieve a reasonable number of lifecycle categories and cell numbers for each category, we decided to use the following approach. The lifecycle category variable is developed using a systematic method. First, the sample is categorized into three age groups: young (under 35), middle-aged (35-64), and old ( 65 or older). Next, each age group is divided into two groups based on the respondent's marital status (married or unmarried). Finally, each age/marriage-specific stage is further separated into three groups based on presence and age of children (in the young and middle-aged group) and presence of financial independence in the old group. As a result, 15 mutually exclusive lifecycle stages are created for use in this study:

(1) Age $\leq 35$, unmarried, no children;

(2) Age $\leq 35$, unmarried, with children $<7$;

(3) Age $\leq 35$, unmarried, with children $\geq 7$;

(4) Age $\leq 35$, married (and cohabiting), no children;

(5) Age $\leq 35$, married, with children $<7$;

(6) Age $\leq 35$, married, with children $\geq 7$; 
(7) Age 36-64, unmarried, no children;

(8) Age 36-64, unmarried, with children $<15$;

(9) Age 36-64, unmarried, with children $\geq 15$;

(10) Age 36-64, married, no children;

(11) Age 36-64, married, with children $<15$;

(12) Age 36-64, married, with children $\geq 15$;

(13) Age $\geq 65$, unmarried;

(14) Age $\geq 65$, married, no financial dependents; and

(15) Age $\geq 65$, married, with financial dependents.

Category 13 is not divided into two groups (with or without dependents) because this category

has a small sample size. The weighted distribution of these lifecycle stages is presented in Table

I. More than half of the respondents (53.6 percent) are middle-aged

Table I.

Distribution of lifecycle categories

\begin{tabular}{|c|c|c|}
\hline Lifecycle categories & Count & $\%$ \\
\hline Age $\leqslant 35$, married (and cohabiting), no children & 1,503 & 4.6 \\
\hline Age $\leqslant 35$, married, with children $<7$ & 2,512 & 7.8 \\
\hline Age $\leqslant 35$, married, with children $\geqslant 7$ & 556 & 1.7 \\
\hline Age $\leqslant 35$, unmarried, no children & 2,330 & 7.2 \\
\hline Age $\leqslant 35$, unmarried, with children $<7$ & 737 & 2.3 \\
\hline Age $\leqslant 35$, unmarried, with children $\geqslant 7$ & 403 & 1.2 \\
\hline Age $36-64$, married, no children & 4,117 & 12.7 \\
\hline Age $36-64$, married, with children $<15$ & 4,019 & 12.4 \\
\hline Age $36-64$, married, with children $\geqslant 15$ & 2,833 & 8.8 \\
\hline Age 36-64, unmarried, no children & 4,112 & 12.7 \\
\hline Age $36-64$, unmarried, with children $<15$ & 841 & 2.6 \\
\hline Age $36-64$, unmarried, with children $\geqslant 15$ & 1,414 & 4.4 \\
\hline Age $\geqslant 65$, married, no financial dependents & 3,148 & 9.7 \\
\hline Age $\geqslant 65$, married, with financial dependents & 255 & 0.8 \\
\hline Age $\geqslant 65$, unmarried & 3,590 & 11.1 \\
\hline
\end{tabular}

Notes: Sample size $=32,370$. Weighted analysis on data from 1992-2010 Surveys of Consumer Finance 
(36-64 years old), about a quarter (24.8 percent) are young (35 or younger), and 21.6 percent of them are 65 or older. The majority of the young and middle-aged respondents are married $(56.8$ and 63.3 percent, respectively) and have children (52.3 and 52.5 percent, respectively).

Control variables

Based on previous research (Getter, 2003; Lyons and Fisher, 2006; Sun and Xiao, 2007), several control variables are included in the analyses to indicate income shock (coded as 1 if the statement is true that "income unusually low compared to what you would expect in a 'normal' year"), if receiving public assistance income, household head's education, race, employment status, health, homeownership, holdings of several types of debts (mortgage, credit card, purchase, student loan, and vehicle loan debt), log household annual income and log household financial asset. In addition, survey year is also included as an independent variable to examine the trend of debt delinquent behavior.

Data analyses

A cross-tabulation is used to examine the percent distribution of delinquency by lifecycle categories. A multivariate logistic regression model is conducted to determine which lifecycle categories are more likely to be delinquent and to predict the probabilities of households in debt delinquency by lifecycle categories.

One unique feature of the SCF is that it includes five implicates that are five copies of data in a certain year of the survey, which were produced using sophisticated statistical procedures (Kennickell, 1998). All five implicates provided by the data sets are combined into a single data set for analysis, and the "repeated-imputation inference" method is used to obtain the 
coefficients, standard deviations, and log odds which are more accurate than the results calculated based on one implicate (Kennickell, 1998). In addition, following the practices of many researchers who use SCF data, the sample is weighted in bivariate analyses and unweighted in multivariate logistic analyses.

\section{Results}

Table II shows that based on the weighted nationally representative sample, 6.1 percent of the respondents among American households are delinquent on debts. Ten lifecycle categories have higher than average risks of delinquency. For example, young couples with children aged seven or older have the highest risk, 14.4 percent. The next highest risk groups are young singles with children aged seven or older (13.3 percent) and young singles with children under seven (12.6 percent). Other high-risk groups are middle-aged singles with children aged 15 or older (11.5 percent) and middle-aged singles with children under 15 (11.3 percent). Old couples with no financial dependents have the lowest risk of being delinquent, 1.1 percent.

Logistic analyses show that, compared with the reference category (young couples without children), ten lifecycle categories have statistically higher risk of debt delinquency (Table III). Controlled for other factors, for young couples with children aged seven or older, the odds of being delinquent are 3.2 times the odds for the reference group being delinquent (odds ratio $(\mathrm{OR})=3.172)$, inconsistent with H1. Other lifecycle categories that have higher risks of debt delinquency include, in order from high to low OR: middle-aged singles with children aged 15 or older $(\mathrm{OR}=2.120)$, middle-aged singles with children under $15(\mathrm{OR}=2.029)$, middle-aged couples with children under $15(\mathrm{OR}=1.994)$, old couples with financial dependents $(\mathrm{OR}=1.871)$, young singles with children aged seven or older $(\mathrm{OR}=1.827)$, middle-aged singles without children 
$(\mathrm{OR}=1.798)$, young couples with children under $7(\mathrm{OR}=1.783)$, middle-aged couples with children 15 or older $(\mathrm{OR}=1.772)$, middle-aged singles with children under seven $(\mathrm{OR}=1.485)$, and middle-aged couples without children $(\mathrm{OR}=1.389)$.

Several control variables also show significant effects on debt delinquency. Controlling for other factors, respondents surveyed in 2010, 2004, 2001, and 1998 are more likely to be delinquent on debt than respondents surveyed in 1992 (Table III). After controlling for other factors, respondents who have completed high school or

Table II.

Debt delinquency by lifecycle categories

\begin{tabular}{lll}
\hline Lifecycle stage & Not delinquent (\%) & Delinquent (\%) \\
\hline
\end{tabular}

$\begin{array}{lrl}\text { All families } & 93.9 & 6.1\end{array}$

Age $\geqslant 65$, married, no financial dependents $\quad 98.9 \quad 1.1$

Age $\geqslant 65$, unmarried

$98.2 \quad 1.8$

Age 36-64, married, no children

$95.8-4.2$

Age $\leqslant 35$, married, no children

$94.7 \quad 5.3$

Age $\geqslant 65$, married, with financial dependents $\quad 94.5$

Age 36-64, married, with children $\geqslant 15 \quad 93.5 \quad 6.5$

$\begin{array}{lll}\text { Age 36-64, unmarried, no children } & 93.3 & 6.7\end{array}$

$\begin{array}{lll}\text { Age 36-64, married, with children }<15 & 93.0 & 7.0\end{array}$

$\begin{array}{lll}\text { Age } \leqslant 35 \text {, unmarried, no children } & 92.6 & 7.4\end{array}$

$\begin{array}{lll}\text { Age } \leqslant 35 \text {, married, with children }<7 & 91.3 & 8.7\end{array}$

Age 36-64, unmarried, with children $<15 \quad 88.7 \quad 11.3$

Age 36-64, unmarried, with children $\geqslant 15 \quad 88.5 \quad 11.5$

$\begin{array}{lll}\text { Age } \leqslant 35 \text {, unmarried, with children }<7 & 87.4 & 12.6\end{array}$

$\begin{array}{lll}\text { Age } \leqslant 35 \text {, unmarried, with children } \geqslant 7 & 86.7 & 13.3\end{array}$

Age $\leqslant 35$, married, with children $\geqslant 7 \quad 85.6 \quad 14.4$

Notes: Sample size $=32,370$. Weighted analysis on data from 1992-2010 Surveys of Consumer Finance 


\section{Table III.}

\section{Logistic results on consumer financial delinquency}

\begin{tabular}{|c|c|c|}
\hline Parameter & Coefficients & Odds ratio \\
\hline Intercept & $-2.6513^{* * * *}$ & \\
\hline \multicolumn{3}{|c|}{ Lifecycle stages (reference category: age $\leqslant 35$, married, no children) } \\
\hline Age $\leqslant 35$, married, with children $<7$ & $0.5781 * * *$ & 1.783 \\
\hline Age $\leqslant 35$, married, with children $\geqslant 7$ & $1.1545^{* * * *}$ & 3.172 \\
\hline Age $\leqslant 35$, unmarried no children & 0.2282 & 1.256 \\
\hline Age $\leqslant 35$, unmarried, with children $<7$ & $0.3955^{*}$ & 1.485 \\
\hline Age $\leqslant 35$, unmarried, with children $\geqslant 7$ & $0.6029^{* *}$ & 1.827 \\
\hline Age $36-64$, married, no children & $0.3286^{*}$ & 1.389 \\
\hline Age 36-64, married, with children $<15$ & $0.6900^{* * * *}$ & 1.994 \\
\hline Age $36-64$, married, with children $\geqslant 15$ & $0.5722^{* * * *}$ & 1.772 \\
\hline Age $36-64$, unmarried, no children & $0.5867^{* * * *}$ & 1.798 \\
\hline Age $36-64$, unmarried, with children $<15$ & $0.7075^{* * *}$ & 2029 \\
\hline Age $36-64$, unmarried, with children $\geqslant 15$ & $0.7513^{* * * *}$ & 2120 \\
\hline Age $\geqslant 65$, married, no financial dependents & -0.3172 & 0.728 \\
\hline Age $\geqslant 65$, married, with financial dependents & 0.6266 & 1.871 \\
\hline Age $\geqslant 65$, unmarried & 0.0420 & 1.043 \\
\hline \multicolumn{3}{|l|}{ Survey year (reference category: 1992) } \\
\hline 1996 & 0.1505 & 1.162 \\
\hline 1998 & $0.3175^{* * *}$ & 1.374 \\
\hline 2001 & $0.3415^{* * *}$ & 1.407 \\
\hline 2004 & $0.4472^{* * * *}$ & 1.564 \\
\hline 2007 & 0.1778 & 1.195 \\
\hline 2010 & $0.5313^{* * *}$ & 1.701 \\
\hline \multicolumn{3}{|c|}{ Education (neference category $=$ less than high school DIPLOMA) } \\
\hline High School Diploma/GED & $0.2000^{*}$ & 1.221 \\
\hline Some College & $0.3629 * * *$ & 1.437 \\
\hline Bachelor's Degree & -0.0266 & 0.974 \\
\hline Graduate/Professional Degree & -0.0992 & 0.906 \\
\hline \multicolumn{3}{|l|}{ Race (reference category $=$ white) } \\
\hline Black & $0.2770^{* * * *}$ & 1.319 \\
\hline Hispanic & -0.1040 & 0.901 \\
\hline Other & 0.0085 & 1.009 \\
\hline \multicolumn{3}{|c|}{ Employment status (reference category = salary earner) } \\
\hline Self-employed & -0.0108 & 0.989 \\
\hline Retired & $-0.3080^{* * *}$ & 0.735 \\
\hline Not currently working & -0.0979 & 0.907 \\
\hline \multicolumn{3}{|l|}{ Self-perceived health (reference category $=$ poor) } \\
\hline Fair & $-0.4302^{* * * *}$ & 0.650 \\
\hline Good & $-0.7291 * * *$ & 0.482 \\
\hline Excellent & $-1.1060^{* * * *}$ & 0.331 \\
\hline Home ownership & $-0.6570^{* * * *}$ & 0.518 \\
\hline Have credit card debt & $0.3497 * * *$ & 1.419 \\
\hline Have mortgage & $0.5683^{* * * *}$ & 1.765 \\
\hline Have purchase loan & $1.7411^{* * *}$ & 5.704 \\
\hline Have vehicle loan & $-0.4463^{* * * *}$ & 0.640 \\
\hline Have student loan & $0.2990^{* * *}$ & 1.349 \\
\hline Log (annual household income) & -0.0327 & 0.968 \\
\hline Log (financial assets) & $-0.1486^{* * * *}$ & 0.862 \\
\hline Income shock & $0.6343^{* * * *}$ & 1.886 \\
\hline Using public assistance & 0.2698 & 1.310 \\
\hline Concordance & $84.3 \%$ & \\
\hline$\chi^{2}$-test of likelihood ratio & $2,757.5793^{* * *}$ & \\
\hline
\end{tabular}

Notes: Sample size $=32,370$. Unweighted analysis on data from 1992-2010 Surveys of Consumer Finance. $* p<0.05, * * p<0.01, * * * p<0.001$

have received some college education are more likely to be delinquent on debt than those with lower than high school education ( $\mathrm{OR}=1.221$ and 1.437 , respectively). The odds of being 
delinquent on debt for blacks are 31.9 percent higher than the odds of otherwise similar whites. Having credit card debt, mortgage, purchase loans, and student loans increase the risk of debt delinquency $(\mathrm{OR}=1.419,1.765,5.704,1.349$, respectively). Consistent with Getter (2003), experiencing an adverse income shock increases the risk of debt delinquency.

Factors associated with lower odds of delinquency risk include financial asset and home ownership, which is consistent with previous research (Getter, 2003). Having vehicle loans also reduces debt delinquency risk. Using public assistance does not show effects on debt delinquency, which is partially consistent with previous research (Lyons and Fisher, 2006). The odds of being delinquent for retired respondents are 26.5 percent less than the odds for salary earners. Self-perceived health is negatively associated with being delinquent on debt. The odds of being delinquent for those who report excellent health is only 33.1 percent less than the odds for those who believe they have poor health.

Predicted probabilities of debt delinquency by lifecycle categories and type of debt ownership are presented in Table IV. Regardless of debt ownership, young couples with children aged seven or older have the highest estimated risk of being debt delinquent, followed by middle-aged singles with children age 15 or older, middle-aged singles with children under 15 , middle-aged couples with children under 15 , and old couples with financial dependents. For example, for households with only credit card debt, the predicted probability of young couples with children aged seven or older being delinquent is 4.85 percent, 1.56 percentage points higher than the second-highest risk group. Other high-risk lifecycle stages for credit card delinquency include middle-aged singles with children age 15 or older (risk probability=3.29 percent), middle-aged 
singles with children under 15 (risk probability $=3.16$ percent), and middle-aged couples with children under 15 (3.10 percent).

The lowest predicted probability of being delinquent on credit card debt is from old couples with no financial dependents (risk probability $=1.16$ percent). The patterns of the predicted probability of being delinquent for other types of debt ownership are similar to the pattern for credit card debt owners. However, households with purchase loans are the most likely, and vehicle loan owners are the least likely to be delinquent.

\section{Discussions}

This study examines debt delinquent risk by family lifecycle categories using seven data sets of 1992-2010 SCF in the USA. In total, 15 family lifecycle categories appropriate for American families are constructed. Households in different lifecycle categories are found to have different probabilities of being delinquent on debt repayment. Multiple logistic regression results show that among the 15 household lifecycle categories, the top three most likely to be delinquent are

young couples with children aged seven or older, middle-aged singles with children aged 15 or older, and middle-aged singles with children under 15. Old married couples without financial independents have the lowest odds of being debt delinquent. These findings support H4 and H5.

The findings suggest that younger households are more financially distressed than their older counterparts, which is consistent with $\mathrm{H} 1$ and in line with previous research (Yilmazer and DeVaney, 2005). All three old groups have below average rates of debt delinquency, based on the bivariate results. All old groups have lower OR 
Table IV.

Predicted probabilities of debt delinquency by lifecycle stage categories and type of debt ownership

\begin{tabular}{|c|c|c|c|c|c|}
\hline Lifecycle stage category & $\begin{array}{l}\text { Have credit } \\
\text { card debt } \\
(\%)\end{array}$ & $\begin{array}{c}\text { Have } \\
\text { mortgage } \\
(\%)\end{array}$ & $\begin{array}{c}\text { Probability } \\
\text { Have } \\
\text { purchase } \\
\text { loan (\%) }\end{array}$ & $\begin{array}{c}\text { Have } \\
\text { vehicle } \\
\text { loan (\%) }\end{array}$ & $\begin{array}{c}\text { Have } \\
\text { student } \\
\text { loan (\%) }\end{array}$ \\
\hline Age $\leqslant 35$, married, no children & 1.6 & 2.0 & 6.1 & 0.7 & 1.5 \\
\hline Age $\leqslant 35$, married, with children $<7$ & 2.8 & 3.4 & 10.3 & 1.3 & 2.6 \\
\hline Age $\leqslant 35$, married, with children $\geqslant 7$ & 4.8 & 6.0 & 17.0 & 2.2 & 4.6 \\
\hline Age $\leqslant 35$, unmarried no children & 2.0 & 2.4 & 7.5 & 0.9 & 1.9 \\
\hline Age $\leqslant 35$, unmarried, with children $<7$ & 2.3 & 2.9 & 8.8 & 1.1 & 2.2 \\
\hline Age $\leqslant 35$, unmarried, with children $\geqslant 7$ & 2.9 & 3.5 & 10.6 & 1.3 & 2.7 \\
\hline Age $36-64$, married, no children & 2.2 & 2.7 & 8.2 & 1.0 & 2.1 \\
\hline Age $36-64$, married, with children $<15$ & 3.1 & 3.8 & 11.4 & 1.4 & 3.0 \\
\hline Age $36-64$, married, with children $\geqslant 15$ & 2.8 & 3.4 & 10.3 & 1.3 & 2.6 \\
\hline Age $36-64$, unmarried, no children & 2.8 & 3.5 & 10.4 & 1.3 & 2.7 \\
\hline Age $36-64$, unmarried, with children $<15$ & 3.2 & 3.9 & 11.6 & 1.4 & 3.0 \\
\hline Age $36-64$, unmarried, with children $\geqslant 15$ & 3.3 & 4.1 & 12.0 & 1.5 & 3.1 \\
\hline $\begin{array}{l}\text { Age } \geqslant 65 \text {, married, no financial } \\
\text { dependents } \\
\text { Age } \geqslant 65 \text {, married, with financial }\end{array}$ & 1.2 & 1.4 & 4.5 & 0.5 & 1.1 \\
\hline dependents & 2.9 & 3.6 & 10.8 & 1.3 & 2.8 \\
\hline Age $\geqslant 65$, unmarried & 1.6 & 2.0 & 6.3 & 0.8 & 1.6 \\
\hline
\end{tabular}

of delinquency than all young and middle-aged stages with two exceptions - one being young, single, without children and the other being young, married, without children. However, the middle-aged groups are more likely than their younger counterparts to be debt delinquent, as predicted by theory. Five out of six young groups and five out of six middle-aged groups have higher than average rates of delinquency based on bivariate analyses. Five out of six middle-aged categories have high OR (1.5 or higher), while three out of six young categories do so. 
$\mathrm{H} 2$ is partially supported by findings of middle-age couples, which indicates unmarried households are more likely to be debt delinquent than married households, controlling for several demographic and economic factors. All three sets of comparable categories in the middle-age headed households show the same pattern. For example, in Table III, the OR being delinquent of middle-aged married households with children aged 15 years or older is 1.8 , while that of their unmarried counterparts is 2.1 .

Presence of children seems to be another important factor contributing to debt delinquency, consistent with H3. Eight of nine categories with children have not only higher than average observed risk of delinquency, but also high OR of being debt delinquent after controlling for other factors. For example, compared to young married couples without children, the OR of young married couples with young children $(<7)$ or older children $(\geq 7)$ are 1.8 or 3.2 , respectively. In other words, compared to their childless counterparts, young married couples with younger children are 80 percent more likely to be debt delinquent, and those with older children are 220 percent more likely to be so.

To observe individual debt delinquency behavior over actual lifecycle stages, longitudinal data should be examined. However, because the purpose of this study is to depict an overall picture of debt delinquency by lifecycle categories, this study is limited to analyses of cross-sectional data that generate results describing the national patterns of debt delinquent behavior by lifecycle categories. Our study has employed multiple years' national data sets and utilized lifecycle categories specifically designed for American families, which are our unique contributions to the 
literature. Findings reported in this study provide unique insights to understand family debt behavior over family lifecycle stages.

\section{Limitations and future research directions}

Three limitations of this study should be acknowledged. First, this study used data from multiple cross-sectional data sets, and the findings of the study can only be viewed as average behavioral patterns of households in various lifecycle stage categories, not the actual lifecycle stages. Future research may need to use longitudinal data sets to examine this important research question.

Second, the findings of this study only depict the behavioral patterns of household debt delinquency risks for American households. Future research should be encouraged to use data from other countries to identify commonalities and differences of consumer debt delinquent behaviors at the international level.

Third, the findings show that high-risk groups include consumers with some specific debts, such as credit card debt, home mortgages, purchase loans, or student loans. For example, for consumers with purchase loans, their OR of being delinquent are 5.7 times as high as the odds of those who do not hold this type of debt. Households with a vehicle loan, on the contrary, have an OR that is 36.0 percent lower than those who did not have a vehicle loan. Because of the space limitation, we have not explored the reasons for these findings. Future research on the reason that certain types of debts increase the probability of being debt delinquent would be useful.

\section{Managerial implications}


The findings of this study suggest that consumers in various lifecycle stage categories have diverse risks in terms of debt delinquency, which has implications for bank managers. Managers should be aware that lifecycle category is an important factor in consumer debt delinquency. Special attention should be given to households with dependent children, because these households have a higher tendency to be delinquent on their loans. For example, households with financially dependent children in three lifecycle categories have much higher risks of debt delinquency than the reference group (married young households without children), and managers should pay special attention to them in business decisions. Our findings suggest that in terms of debt delinquency risks, younger households, unmarried households and households with children generally have a higher risk compared to their counterparts with similar demographic and economic factors.

The findings of this study can also be used to segment the consumer loan market based on borrowers' lifecycle categories. The purpose of this segmentation is to identify relative attractiveness of customers and, ultimately, the profitability of these segments. Once the segmentation is done, managers can develop differential strategies to attract and retain customers in different lifecycle categories. For example, banks that want to focus on low-risk customers and the low-risk debt market need to be cautious about making loans to households at certain lifecycle stages (e.g. young unmarried people with children). After the segmentation, different client groups can be priced differently based on their risk of being late. Bank professionals should keep a balance between providing consumer loan access and preventing debt delinquency risk to ensure the win-win game that achieves the bank's profitability and productivity and the consumers' economic security and financial well-being. 
This study's findings also have implications for consumer financial educators. Results from the multivariate logistic models can be used to create charts to display the debt delinquency trajectories of at-risk households across various lifecycle categories (see Figure 1 as an example). In addition, findings of this research suggest that financial educators should target at-risk households at certain lifecycle categories to help them understand the undesirable consequences of debt delinquency and teach them skills to use before they have debt problems.

Based on findings from the multiple logistic analyses, at-risk groups also include those who are black, renters, with poor health, with a relatively low education level (a high school diploma or some college), and experiencing an income shock. Financial educators should tailor their services to these households to help them reduce the likelihood of being debt delinquent. For example, for those who are experiencing an income shock, educators should focus on trainings to help them get back into the workforce, to adjust their expenses downward, and to manage the type of debt they hold in order to reduce their likelihood of being delinquent in debt payments. Figure 1.

A hypothesized case: risk of debt delinquency over lifecycle among credit card debt holders

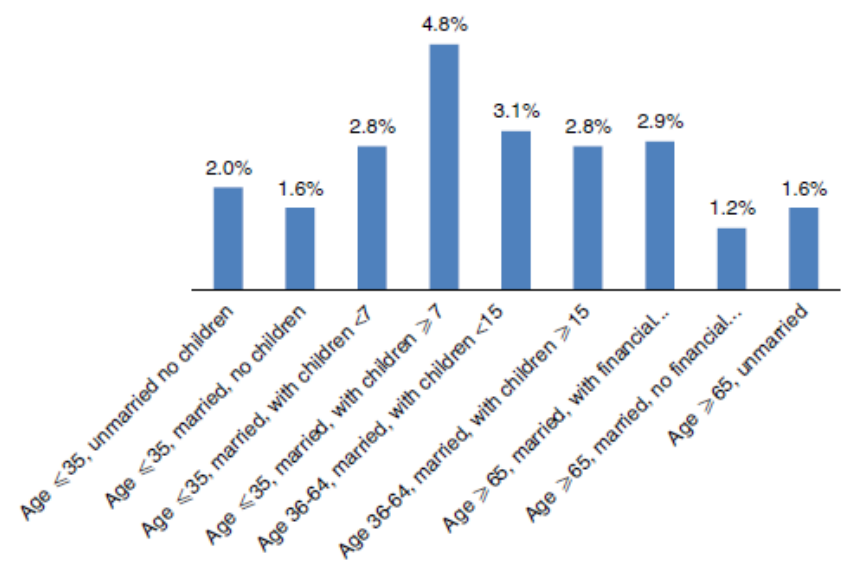




\section{References}

Aizcorbe, A., Kennickell, A. and Moore, K. (2003), "Recent changes in US family finances: evidence from the 1998 and 2001 survey of consumer finances”, Federal Reserve Bulletin, Vol. 89 No. 1, pp. 1-32.

Attanasio, O.P. and Weber, G. (2010), “Consumption and saving: models of intertemporal allocation and their implications for public policy", Journal of Economic Perspective, Vol. 48 No. 3, pp. 693-751.

Baek, E. and Hong, G.-S. (2004), "Effects of family life-cycle stages on consumer debts", Journal of Family and Economic Issues, Vol. 25 No. 3, pp. 359-385.

Blankson, C., Paswan, A. and Boakye, K.G. (2012), “College students' consumption of credit cards", International Journal of Bank Marketing, Vol. 30 No. 7, pp. 567-585.

Bricker, J., Kennickell, A.B., Moore, K.B. and Sabelhaus, J. (2012), “Changes in US family finances from 2007 to 2010: evidence from the survey of consumer finances”, Federal Reserve Bulletin, Vol. 98 No. 2, pp. 1-80.

Browning, M. and Crossley, T. (2001), "The life-cycle model of consumption and saving”, The Journal of Economic Perspectives, Vol. 15 No. 3, pp. 3-22.

Bucks, B., Kennickell, A. and Moore, K. (2006), "Recent changes in US family finances: evidence from the 2001 and 2004 survey of consumer finances", Federal Reserve Bulletin, Vol. 92 No. 2, pp. A1-A38.

Bucks, B., Kennickell, A., Mach, T. and Moore, K. (2009), "Changes in US family finances from 2004 to 2007: evidence from the survey of consumer finances", Federal Reserve Bulletin, Vol. 95 No. 2, pp. A1-A55. 
Canner, G. and Luckett, C. (1990), “Consumer debt repayment woes: insights from a household survey", Journal of Retail Banking Services, Vol. 12 No. 1, pp. 55-55.

Demos and Center for Responsible Lending (2005), The Plastic Safety Net: The Reality Behind Debt in America - Findings From a National Household Survey of Credit Card Debt Among Low- and Middle-income Households, Demos and Center for Responsible Lending, New York, NY.

Devlin, J.F., Worthington, S. and Gerrard, P. (2007), “An analysis of main and subsidiary credit card holding and spending”, International Journal of Bank Marketing, Vol. 25 No. 2, pp. 89101.

Du, R. and Kamakura, W. (2006), "Household life cycles and lifestyles in the United States", Journal of Marketing Research, Vol. 43 No. 1, pp. 121-132.

Dynan, K.E. (2009), “Changing household financial opportunities and economic security”, The Journal of Economic Perspectives, Vol. 23 No. 4, pp. 49-68.

Foscht, T., Maloles, C. III, Swoboda, B. and Chia, S.-L. (2010), “Debit and credit card usage and satisfaction: who uses which and why - evidence from Austria", International Journal of Bank Marketing, Vol. 28 No. 2, pp. 150-165.

Fritzche, D.J. (1981), “An analysis of energy consumption patterns by stage of family life cycle”, Journal of Marketing Research, Vol. 18 No. 2, pp. 227-232.

Getter, D. (2003), "Contributing to the delinquency of borrowers", The Journal of Consumer Affairs, Vol. 37 No. 1, pp. 86-100.

Getter, D. (2006), “Consumer credit risk and pricing”, Journal of Consumer Affairs, Vol. 40 No. 1, pp. 41-63. 
Hisrich, R. and Peters, M. (1974), "Selecting the superior segmentation correlates”, Journal of Marketing, Vol. 38 No. 3, pp. 60-60.

Johnson, K. (2005), "Recent developments in the credit card market and the financial obligations ratio”, Federal Reserve Bulletin, Vol. 91 No. 4, pp. 473-486.

Kennickell, A.B. (1998), "Multiple imputation in the survey of consumer finances”, Federal Reserve Board SCF Working Paper, available at: www.federalreserve.gov/pubs/ oss/oss2/papers/impute98.pdf (accessed November 15, 2013).

Lander, D.A. (2008), "Regulating consumer lending”, in Xiao, J.J. (Ed.), Handbook of Consumer Finance Research, Springer, New York, NY, pp. 387-410.

Lansing, J.B. and Kish, L. (1957), "Family life cycle as an independent variable”, American Sociological Review, Vol. 22 No. 5, pp. 512-519.

Lansing, J.B. and Morgan, J.N. (1955), Consumer Finances over the Life Cycle: Consumer Behavior, New York University Press, New York, NY.

Lyons, A. (2003), "How credit access has changed over time for US households", The Journal of Consumer Affairs, Vol. 37 No. 2, pp. 231-255.

Lyons, A. and Fisher, J. (2006), "Gender differences in debt repayment problems after divorce”, The Journal of Consumer Affairs, Vol. 40 No. 2, pp. 324-346.

McCloud, L. and Dwyer, R.E. (2011), "The fragile American: hardship and financial troubles in the 21 st century", Sociological Quarterly, Vol. 52 No. 1, pp. 13-35.

Modigliani, F. (1986), "Life cycle, individual thrift, and the wealth of nations", The American Economic Review, Vol. 76 No. 3, pp. 297-297. 
Modigliani, F. and Brumberg, R. (1954), Utility Analysis and the Consumption Function: An Interpretation of Cross-section Data, Post Keynesian Economics, Rutgers University Press, New Brunswick, NJ.

Moorman, D. and Garasky, S. (2008), “Consumer debt repayment behavior as a precursor to bankruptcy”, Journal of Family and Economic Issues, Vol. 29 No. 2, pp. 219-233.

Ryan, A., Trumbull, G. and Tufano, P. (2010), “A brief postwar history of US consumer finance", Business History Review, Vol. 85 No. 3, pp. 461-498.

Sun, J. and Xiao, J.J. (2007), "Economic and demographic differences in debt delinquent behavior", Proceedings of American Council on Consumer Interests, Consumer Interest Annual, Baltimore, MD, available at: www.thefreelibrary.com/Economicpandpdemographicpdifferencespinpdebtpdelinquentpbeha vior.-a0167842516 (accessed November 15, 2013).

Thaler, R.H. (2000), "From homo economicus to homo sapiens", Journal of Economic Perspectives, Vol. 14 No. 1, pp. 133-141.

Wagner, J. and Hanna, S. (1983), “The effectiveness of family life cycle variables in consumer expenditure research", Journal of Consumer Research, Vol. 10 No. 3, pp. 281-281.

Wilkes, R. (1995), “Household life-cycle stages, transitions, and product expenditure”, Journal of Consumer Research, Vol. 22 No. 1, pp. 27-42.

Worthington, S. (1998), “The card centric distribution of financial services: a comparison of Japan and the UK”, International Journal of Bank Marketing, Vol. 16 No. 5, pp. 211-220. Worthington, S. and Horne, S. (1998), “A new relationship marketing model and its application in the affinity credit card market", International Journal of Bank Marketing, Vol. 16 No. 1, pp. 9-44. 
Xiao, J.J. and Yao, R. (2011), "Debt holding and burden by family structure: patterns and trends in 1989-2007”, working paper in Social Science Research Network, available at: http:// papers.ssrn.com/sol3/papers.cfm?abstract_id $1 / 41799362$ (accessed November 15, 2013).

Xiao, J.J., Ford, M. and Kim, J. (2011), “Consumer financial behavior: an interdisciplinary review of selected theories and research”, Family and Consumer Science Research Journal, Vol. 39 No. 4, pp. 399-414.

Yilmazer, T. and DeVaney, S. (2005), "Household debt over the life cycle", Financial Services Review, Vol. 14 No. 4, pp. 285-304. 